\title{
Estimation of regional differences in wind erosion sensitivity in Hungary
}

\author{
G. Mezôsi ${ }^{1}$, V. Blanka ${ }^{1}$, T. Bata ${ }^{1}$, F. Kovács ${ }^{1}$, and B. Meyer ${ }^{2}$ \\ ${ }^{1}$ Department of Physical Geography and Geoinformatics, University of Szeged, Szeged, Hungary \\ ${ }^{2}$ Institut für Geographie, Universität Leipzig, Leipzig, Germany \\ Correspondence to: V. Blanka (blankav@geo.u-szeged.hu)
}

Received: 4 June 2013 - Published in Nat. Hazards Earth Syst. Sci. Discuss.: 11 September 2013 Revised: 3 December 2014 - Accepted: 13 December 2014 - Published: 13 January 2015

\begin{abstract}
In Hungary, wind erosion is one of the most serious natural hazards. Spatial and temporal variation in the factors that determine the location and intensity of wind erosion damage are not well known, nor are the regional and local sensitivities to erosion. Because of methodological challenges, no multi-factor, regional wind erosion sensitivity map is available for Hungary. The aim of this study was to develop a method to estimate the regional differences in wind erosion sensitivity and exposure in Hungary.

Wind erosion sensitivity was modelled using the key factors of soil sensitivity, vegetation cover and wind erodibility as proxies. These factors were first estimated separately by factor sensitivity maps and later combined by fuzzy logic into a regional-scale wind erosion sensitivity map. Large areas were evaluated by using publicly available data sets of remotely sensed vegetation information, soil maps and meteorological data on wind speed. The resulting estimates were verified by field studies and examining the economic losses from wind erosion as compensated by the state insurance company. The spatial resolution of the resulting sensitivity map is suitable for regional applications, as identifying sensitive areas is the foundation for diverse land development control measures and implementing management activities.
\end{abstract}

\section{Introduction}

One of the most serious natural hazards in the Carpathian Basin, resulting from land use practices, is wind erosion on arable lands. The incidence of wind erosion and the rate of the damage are determined by several environmental factors, such as soil texture, lithology, climate, vegetation and human land use effects. Variations in these factors result in different regional and local sensitivities to wind erosion. According to the "Map of potential wind erosion of Hungary" by Lóczy et al. (2012), 26.5\% of Hungary is affected strongly or moderately by wind erosion, where the critical wind speed of erosive winds is lower than $8.5 \mathrm{~m} \mathrm{~s}^{-1}$. They find that in $17.1 \%$ of the country, where sand and loamy sandy soils cover the surface and the critical friction velocity is lower than $6.5 \mathrm{~m} \mathrm{~s}^{-1}$, the effects of wind erosion are high, moreover approximately $9.4 \%$ of the country is moderately affected, where sandy loam soils occur and the critical friction velocity is $6.5-8.5 \mathrm{~m} \mathrm{~s}^{-1}$. However, this map is based only on soil texture class and critical wind speed, whereas other factors are neglected. Thus, this map does not provide a full picture of the hazard.

Estimating wind erosion hazard is a major challenge due to the limited calculation methods for larger areas. However, a strong demand exists for effective methods of regional-scale analysis to estimate wind erosion hazards and sensitivities, since regional scale is suitable for environmental, landscape or spatial planning applications of agricultural and environmental programs (Jaedicke et al., 2008).

Therefore, the aim of this study was to develop a method to identify the areas exposed to wind erosion in Hungary. No multi-factor, regional scale wind erosion sensitivity map exists for Hungary due to the deficiency of suitable methods. The available wind erosion map described above considers only the soil texture and the critical friction velocity of the grain sizes of the soil types (Lóki and Négyesi, 2009; Szabó et al., 1994), and it has not been verified to explain the full picture of wind erosion hazard. The general lack of field measurements and the complexity of the required data sets 
(e.g. soil moisture) and measurement techniques inhibit the detailed mapping of wind erosion hazard.

Whereas most of the regional-scale analyses originated from the plot-sized models, our research involves a regionalscale calculation requiring data at a resolution of approximately $100 \times 100 \mathrm{~m}$. The parameters and relationships on the scale of plots specify the range and the thresholds of each factor, but these relationships cannot be used at regional scales (Zobeck et al., 2000).

To achieve the goal of providing a regional-scale wind erosion sensitivity map the main influential factors, such as soil erodibility, vegetation and wind speed characteristics, were estimated separately in factor sensitivities and in combination via a fuzzy logic method (Klir and Yuan 1995; Shi et al., 2010; Borrelli et al., 2014) into a regional-scale wind erosion sensitivity map for Hungary. The verification of this type of regional-scale analysis is difficult, however, it is still important, thus the reality of the created sensitivity map was tested by field studies and data of economic losses.

\subsection{Wind erosion modelling in local and regional scale}

Bagnold (1941) identified the basic relationship between soil texture and wind characteristics and worked out a method for calculating the rate of wind erosion. This concept was developed further by creating and improving the wind erosion equations (WEQ - Wind Erosion Equation and RWEQ Revised Wind Erosion Equation) and by deriving other relationships using different methodologies, for example, WEPS - the Wind Erosion Prediction System, the Australian Land Erodibility Model (AUSLEM) (Fryrear, 1998; Fryrear et al., 1998; Woodruff and Siddoway, 1965) and the USDA National Agronomy Manual 502 standard (Hagen, 2004; NAM, 2002; Webb et al., 2006). These models were developed based on extensive field measurements and experiments, but several limiting factors, e.g. regarding the exact wind path length or the surface roughness, are missing due to the lack of accurate measuring or estimation methods. These equations and models can be tailored to local conditions based on extensive empirical experience at small scales, but only when accurate data are available. Several methods exist and are widely applied, but each method has methodological limitations (NAM, 2002).

The models and calculations that have been used for plotsized analyses (e.g. WEQ, WEPS, RWEQ) are mainly effective only at the scale of the plots analysed (Funk et al., 2004; NAM, 2002). These approaches are typically process-based models that consider several factors (e.g. surface roughness or wind path length), and the output result can be the amount of dust flux or even the rate of deflation. However, the applied mathematical and physical relationships cannot be simply scaled up to regional applications (NAM, 2002; Webb et al., 2006).

The importance of the contributing factors depends on the scale of the investigation; thus, at larger scales, different fac-

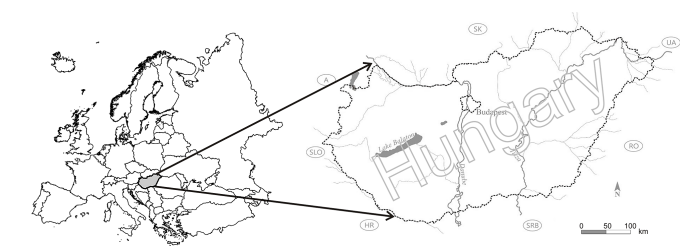

Figure 1. Location of the study area.

tors and different relationships can emerge (Kirkby et al., 1996). However, even at regional scale, the amount of soil loss caused by wind erosion is dependent on climate, soil and vegetation parameters. Moreover, agricultural techniques can have a significant effect (Gomes et al., 2003; Leenders et al., 2005; Tibke, 1988). The few existing calculation methods for regional-scale analyses are primarily derived from the plotsized WEQ or RWEQ models. For example, the method of Zobeck et al. (2000) employed data on soil erosion from field investigations. The applied agro-techniques and agricultural land use units were simply scaled up using GIS methods to calculate the regional wind erosion potential. Other methods integrate data from atmospheric models and soil properties. In the study of Shao and Leslie (1997) measured wind transport data from a one-week survey, were scaled up to the continental scale of Australia by GIS methods, resulting in estimates that were generally problematic, because of the spatial validity of the data. By testing the calibration of RWEQ on Syrian study sites up to 150 ha in size, it was possible to acquire regional-scale results of good quality (Buschiazzo et al., 1999; Fryrear et al., 1998; Youssef et al.; 2012). Nevertheless, the plot-sized models have intense data requirements that are difficult to meet even on the local scale. The need for a regional-scale model that uses less input data is clear (Böhner et al., 2003).

\section{Study area}

In Hungary (Fig. 1), large areas are covered by unconsolidated sandy and silty sediments, mostly of Pleistocene fluvial, lacustrine or aeolian origin (Mezősi, 2011). More than $60 \%$ of the relatively flat area is under agriculture, and the vegetation cover opens and closes on annual and seasonal schedules according to the agricultural crop rotation.

The yearly mean precipitation is $500-700 \mathrm{~mm}$; the average temperature is $10-11{ }^{\circ} \mathrm{C}$ (1961-1990) (Péczely, 1998). The countrywide yearly average wind speed (between 2000 and 2009 ) is $2-4 \mathrm{~m} \mathrm{~s}^{-1}$ (Fig. 2a) and varies throughout the year. The monthly average wind speed (between 1998 and 2008) increases continuously in the first months of the year, and the highest monthly average wind speed is characteristically in March and April (MET, 2012a). The average wind speed reaches its maximum in April and number of days on which the maximum wind speed is over $10 \mathrm{~m} \mathrm{~s}^{-1}$ is also the highest in this month (MET, 2012a) (Fig. 2b). The average wind 

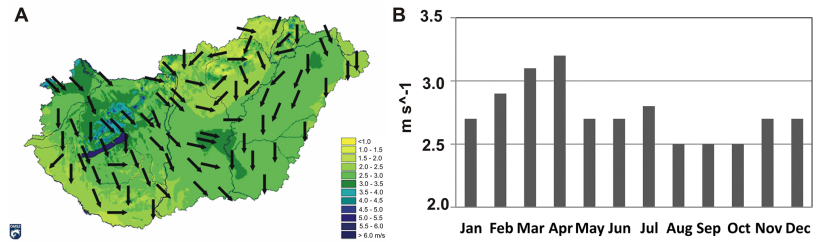

Figure 2. (a) Yearly average (in the period of 2000-2009) wind speed and dominant wind direction in Hungary (arrow lengths do not indicate wind speed, only the direction of dominant wind is shown) (source: MET, 2012b) and (b) the monthly average wind speeds at Budapest between 1998 and 2008 (source: MET, 2012c).

speed in the months most vulnerable to soil erosion (MarchApril) is $3.0-3.2 \mathrm{~m} \mathrm{~s}^{-1}$. The main wind direction of winds above $5 \mathrm{~m} \mathrm{~s}^{-1}$ (which are important in inducing erosion) is towards the north-west (Lyles and Krauss, 1971) (Fig. 2a). The changes in precipitation in the last century have also had a negative effect on wind erosion, as precipitation has decreased most during the spring months, with the rate of decrease of nearly $20 \%$ between 1901 and 2010 (Lakatos et al., 2012). The lithological, climatic, vegetation and agricultural factors of the area are parameters that influence the extent of the wind erosion hazard.

\section{Data and methods}

\subsection{Data}

Calculation methods from plot-sized models cannot be applied without modification and new combinations of data sets at a regional scale. However, the identified relationships between parameters are also relevant to the regional scale. Thus at a regional scale, the three controlling factors of soil, climate and vegetation cover are important for arable land as follows:

- Soil: the texture, grain size distribution and calcium carbonate content (soils with high $\mathrm{CaCO}_{3}$ are more erodible) determine the soil erosion sensitivity;

- Climatic parameters: wind speed and wind energy determine the wind transport capacity and therefore the susceptibility to erosive winds (Fryrear et al., 1998; Munson et al., 2011);

- Vegetation cover: the percentage cover determines the openness and therefore the sensitivity of the vegetation;

- Land cover: land cover data was used to exclude forests and urbanised areas, where wind erosion is not a relevant problem in Hungary.

The data layers used during this analysis are soil, vegetation, wind and land use, and their scale, period of origin and source are described in Table 1. Soil data were available from
Table 1. Data sources for estimating regional wind erosion hazard.

\begin{tabular}{|c|c|c|c|}
\hline Factor & Source & Scale & Period \\
\hline soil & $\begin{array}{l}\text { AGROTOPO } \\
\text { (1991) }\end{array}$ & $1: 25.000$ & - \\
\hline wind & $\begin{array}{l}\text { NOAA National } \\
\text { Climatic Data } \\
\text { Center (NOAA, } \\
\text { 2012) }\end{array}$ & $\begin{array}{l}\text { point data from } \\
52 \text { meteorolog- } \\
\text { ical stations }\end{array}$ & $\begin{array}{l}\text { March and } \\
\text { April from } \\
\text { 2000-2010 }\end{array}$ \\
\hline vegetation & $\begin{array}{l}\text { MOD } 13 \text { Gridded } \\
\text { Vegetation Indices } \\
\text { (NDVI \& EVI) } \\
\text { (USGS, 2012) }\end{array}$ & $250 \times 250 \mathrm{~m}$ & $\begin{array}{l}\text { March and } \\
\text { April from } \\
\text { 2000-2010 }\end{array}$ \\
\hline land cover & $\begin{array}{l}\text { CLC 2006 } \\
\text { (European } \\
\text { Environment } \\
\text { Agency, 2006) }\end{array}$ & $\sim 100 \times 100 \mathrm{~m}$ & 2006 \\
\hline
\end{tabular}

the AGROTOPO spatial soil information system (Agrotopographical Database, 1991). For wind, data from NOAA National Climatic Data Center (NOAA, 2012) were interpolated across the entire country using kriging interpolation, whereas vegetation cover data was available from MODIS NDVI. To exclude those areas where wind erosion is not relevant, the CORINE land cover classes "forest" $(311,312,313)$, "artificial surfaces" (111, 112, 121, 122, 123, 124, 141, 142) and "water bodies" $(511,512)$ (European Environment Agency, 2006) were excluded (Table 1.).

\subsection{Methods}

A full overview of the methodological framework is given in Fig. 3. During the analysis, the contributing factors were modelled based on available or modified data using a sensitivity indicator approach (e.g. the sensitivity of the soil was determined by the soil erodibility based on soil texture classes). The sensitivity of the factors was first calculated separately by using fuzzy analysis (Klir and Yuan, 1995; Shi et al., 2010; Borrelli et al., 2014). Fuzzy logic was introduced by Zadeh (1965). The fuzzy theory deduced that by making the membership function operate over the range of real numbers $[0,1]$, new procedures could be developed. The theory proved to be a development of classic (Boolean) logic (McBratney and Odeh, 1997). Using fuzzy logic in analyses, the geographical processes can be described much more realistically than with true or false in Boolean logic. The fuzzy analysis was carried out by IDRISI software. In this software the relation between two parameters is described by fuzzy membership functions. The fuzzy membership function can be linear, exponential, logarithmic or polynomial (Eastman, 2006). These sensitivity values were averaged into a combined factor sensitivity map to avoid the problem of weighting the factors. Using this estimation method, the sensitivity of an area was not limited to broad classes as highly, moderately or slightly sensitive, and no ranking categories were set up in advance. By applying fuzzy logic, each unit was 


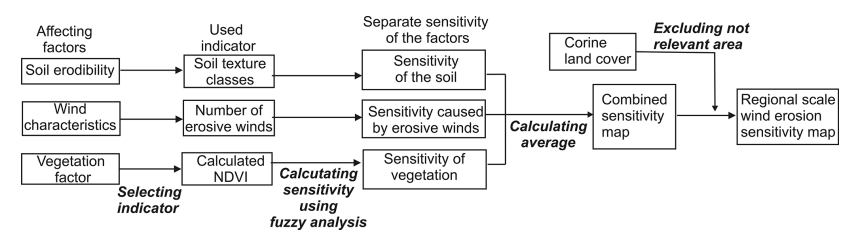

Figure 3. Overview of the applied methodological framework.

assigned a value between 0 and 1 , where 0 means not sensitive and 1 means the maximum sensitivity to wind erosion. Thus 0.4 means that the area is $40 \%$ sensitive; consequently, this area can be regarded as somewhat insensitive. Alternatively, but not applied in our study, it would be possible to produce an empirical matrix with the known threshold values (vegetation cover <10, 10-35, > 35\%; wind speed <3, 3-9, $>9 \mathrm{~m} \mathrm{~s}^{-1}$; soil texture: based on NAM (2002)) to estimate the rate of wind erosion, but such an approach would lose the quantitative aspect of the method and only a qualitative estimation would be applied. The resulting map was overlaid with the CORINE land cover layer to create the overall regional wind erosion sensitivity map (see Fig. 3 for flow chart).

\subsubsection{Analysis of the soil texture}

The soil moisture in Hungary during the spring months (March-April) is usually low; therefore, wind erosion can be especially active at this time of year. The erodibility of the soil was estimated using the texture classes of the Hungarian Agrotopographical Map based on the data of the detailed field surveys carried out for the Kreibig soil map 6070 years ago at a 1:25000 map scale. This map gives the most detailed soil distribution available for Hungary and is still commonly used (Pásztor et al., 2010). However, this map distinguishes only the basic soil textures (sand, sandy silt, silty clay); thus, an approximation to the US standards was adopted when calculating the erodibility index of the soil texture classes (sand, sandy loam, loam, clay loam and clay) based on the modelling results of the NAM (2002) and Klik (2004) as developed initially for plot-size applications (Table 2). This limited classification of soil texture class also explains why the digital soil data are interpreted spatially as a fuzzy information set (Fig. 4). In the case of the soil, the fuzzy membership function was fitted to an exponential relation. The $X$ axis of the fuzzy function represents the soil erodibility index, with values that vary between 0 and $494 \mathrm{tha}^{-1} \mathrm{yr}^{-1}$, whereas the $Y$ axis indicates the fuzzy value, which represents the sensitivity. Low values were given to clay, high values to fine sand, and the intermediate values were described by a monotonically increasing J-shaped fuzzy function. The result of this calculation was a regional-scale map of the sensitivity of soil to wind erosion.

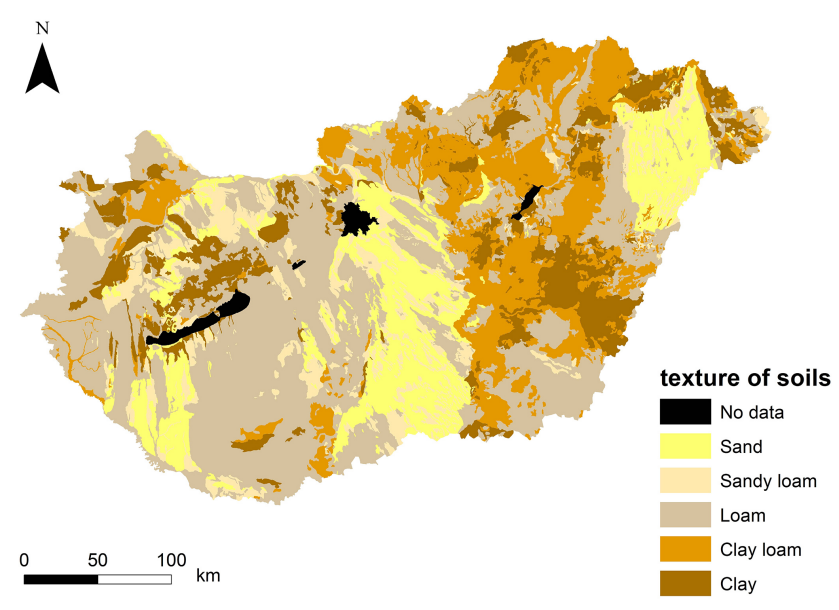

Figure 4. Adopted soil texture classes for Hungary based on an agrotopographical map (AGROTOPO, 1991).

Table 2. Erodibility index of the soil texture classes; based on NAM (2002).

\begin{tabular}{ll}
\hline Texture of soil & Soil erodibility index $\left(\mathrm{tha}^{-1} \mathrm{yr}^{-1}\right)$ \\
\hline sand & 494 \\
sandy loam & 409 \\
loam & 308 \\
clay loam & 196 \\
clay & 246 \\
\hline
\end{tabular}

\subsubsection{Analysis of wind speed}

The sensitivity of an area to wind erosion is determined by its characteristic wind conditions. In Hungary, the average monthly wind speed (between 1998 and 2008) is the highest in March and April. The average wind speed reaches the maximum in April, and the number of days on which the maximum wind speed is over $10 \mathrm{~m} \mathrm{~s}^{-1}$ is also the highest in this month (MET, 2012a). Therefore, March and April are the most important in wind erosion prediction. The calculation of wind speeds used data from 52 meteorological stations (NOAA, 2012). In the analysed months (March-April), the average wind speed varied between $2-4 \mathrm{~m} \mathrm{~s}^{-1}$ for the period of 2000-2011. The highest average values occurred along a north-western to south-eastern gradient, fitted to the plain topography and the dominant wind directions (Fig. 5). The average wind speeds are nevertheless quite low; thus, the averages could not be used to determine the spatial distribution of erosive winds.

We used additional information on the occurrence of high wind speed days to clarify the occurrence of erosive winds. Days with a maximum wind speed above $9 \mathrm{~m} \mathrm{~s}^{-1}$ were used. The $9 \mathrm{~m} \mathrm{~s}^{-1}$ threshold value was defined in accordance with Lóki (2001) as the wind speed that can mobilise the Hungarian chernozem soils. The critical erosion threshold for sandy 


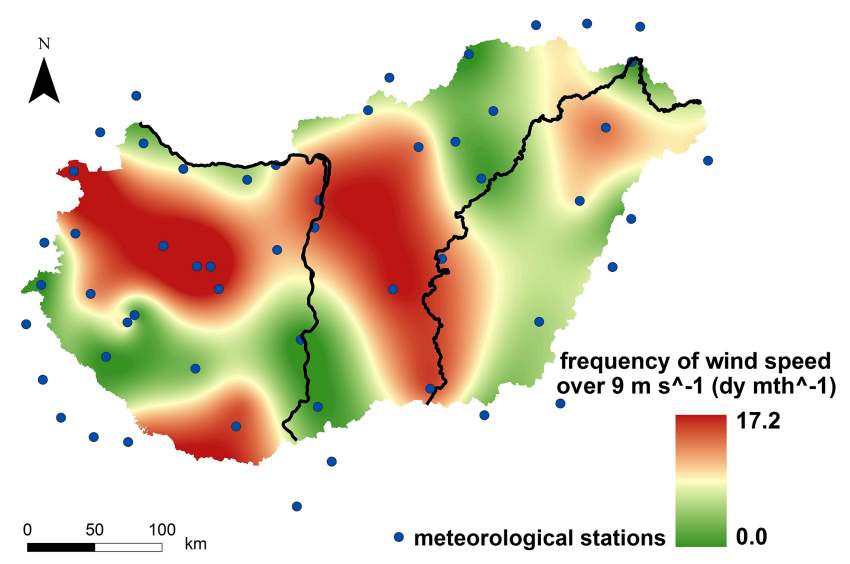

Figure 5. The number of days (day/months) on which the maximum wind speed is over $9 \mathrm{~m} \mathrm{~s}^{-1}$ in March-April in the period of 20002011.

soils and sandy meadow soil is between 5.95 and $6.8 \mathrm{~m} \mathrm{~s}^{-1}$. Generally, a critical wind speed higher than $6 \mathrm{~m} \mathrm{~s}^{-1}$ is a threshold value with which to define wind erosion. Therefore, the applied threshold of $9 \mathrm{~m} \mathrm{~s}^{-1}$ in this study indicates a high probability of erosion.

The spatial distribution of the number of days in March and April with a maximum wind speed higher $9 \mathrm{~m} \mathrm{~s}^{-1}$ in the period 2000-2011 differs by region in Hungary (Fig. 5). The number of days varies from 0 to 17 days.

\subsubsection{Analysis of the vegetation cover}

Vegetation cover is an important factor in wind erosion; if the vegetation cover exceeds $20-35 \%$, wind erosion is reduced significantly (Armbrust and Bilbro, 1997; Munson et al., 2011). The vegetation cover in Hungary in the analysed months (March and April) is usually low in the agricultural areas because the cultivated fields have little cover to protect the soils after the winter.

The vegetation cover for the months of greatest wind erosion was calculated based on remote sensing data. MODIS hyper-spectral images were used, which are available beginning in 2000. For the Carpathian Basin, MODIS images are available with high temporal and spatial resolution, as images are prepared at daily intervals at a $250 \mathrm{~m}$ spatial resolution. The data are freely available in both the raw and pre-processed state from the USGS LP DAAC Data Pool database (USGS, 2012). The large pixel size and broad survey entail some errors (e.g. cloud cover), which were reduced by the maximum value composite (MVC) method. To avoid the inaccuracies that arise from using single images, MVC generates composite images from the best images from 16day periods.

From the 16-day composites, only the images of March (6-21) and April (7-22) were available for the peak wind erosion hazard period. To estimate the vegetation cover the

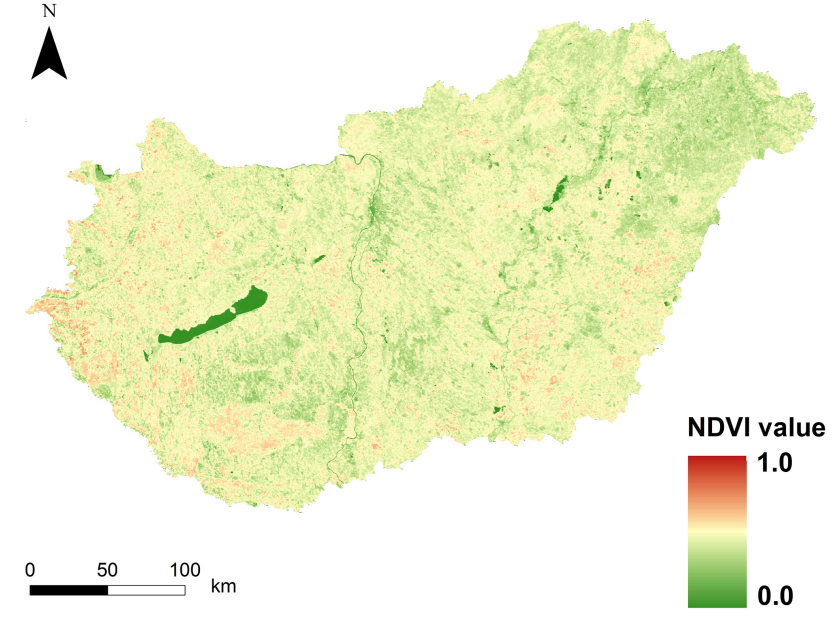

Figure 6. NDVI map from $250 \mathrm{~m}$ resolution MODIS (average values from March-April (in the period of 2000-2011) generated from the 16-day composites).

multispectral NDVI (normalised vegetation index) was used, as a well-established direct relationship exists between the vegetation intensity and the NDVI (Huete et al., 2002). Values close to 0 represent vegetation free surfaces, whereas values close to 1 represent dense vegetation such as forests. The NVDI is calculated as follows:

$\mathrm{NDVI}=(\mathrm{NIR}-R) /(\mathrm{NIR}+R)$,

where $R$ is the red spectral range and NIR is the near-infrared spectral range.

We calculated the average vegetation cover in the hazardous period for the analysed period (2000-2011). The vegetation cover represents the density of the vegetation and thus the sensitivity to wind erosion. This sensitivity was one of the initial data sets of the analysis (Fig. 6).

\subsubsection{Analysis of land cover}

For the focal period of the year, the vegetation cover is usually low for every land cover class; therefore, it is difficult to distinguish the forests from other land cover types on the basis of NDVI. Urbanised areas are also difficult to identify from the NDVI maps. However, wind erosion does not typically occur in forests or urbanised areas. Therefore, land cover type was also employed in the analysis. Forests and urbanised areas were located using the CORINE land cover map (Table 1). The sensitivity map created on the basis of the three analysed factors was overlaid to exclude the forests and urbanised areas.

\subsection{Calculation of sensitivity for the considered factors}

The sensitivity to the contributing factors was calculated by using the fuzzy method. To apply the fuzzy method, it is essential to understand the relationships between the influenc- 


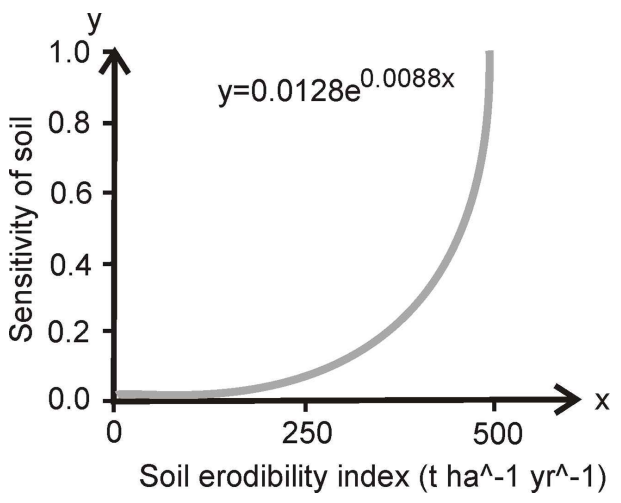

Figure 7. The applied exponential fuzzy membership function of the relation between soil texture (soil erodibility index based on the modelling results of the NAM (2002) and Klik (2004)) and the sensitivity to wind erosion.

ing factors and the rate of wind erosion. In general, the fuzzy membership function can be linear, exponential, logarithmic or polynomial. In the IDRISI Taiga software, these fuzzy membership functions are called to Linear, J-shape, Sigmoidal and User-defined, respectively (Clark Labs, Worcester, MA). Three membership functions are explained and integrated in the following by (a) the relationship of the soil and wind erosion, (b) the relationship between the frequency of erosive winds and wind erosion and (c) the vegetation and wind erosion.

a. The relationship between the mechanical properties of the soil and the rate of wind erosion is exponential, as has been verified on the basis of the plot-sized measurements ( $\mathrm{Li}$ et al., 2005; Skidmore, 1994). The relationship between the two factors is "J-shaped" and monotonically increasing (Fig. 7). The $X$ axis of the fuzzy function represents the soil erodibility index, with values varying between 0 and $494 \mathrm{tha}^{-1} \mathrm{yr}^{-1}$, and the $Y$ axis represents the fuzzy value, which indicates the sensitivity. Low values were given to clay texture, high values to fine sand texture, and the intermediate values between the end values were described by a monotonically increasing J-shape fuzzy function. This relationship indicates that the higher the measured $\mathrm{tha}^{-1} \mathrm{yr}^{-1}$ value of the soil, the higher the sensitivity to wind erosion will be (with $0=$ no sensitivity and $1=100 \%$ or highest sensitivity).

b. The relation between the wind speed and the rate of wind erosion is logarithmic (Böhner et al., 2003; Li et al., 2005). However, due to the available data, the frequency of erosive winds (number of days with a maximum daily wind speed $>9 \mathrm{~m} \mathrm{~s}^{-1}$ ) was used. In this case, the relation between the frequency and wind erosion is linear. Thus, the higher the frequency of the $9 \mathrm{~m} \mathrm{~s}^{-1}$ wind, the greater the sensitivity to wind erosion. For the

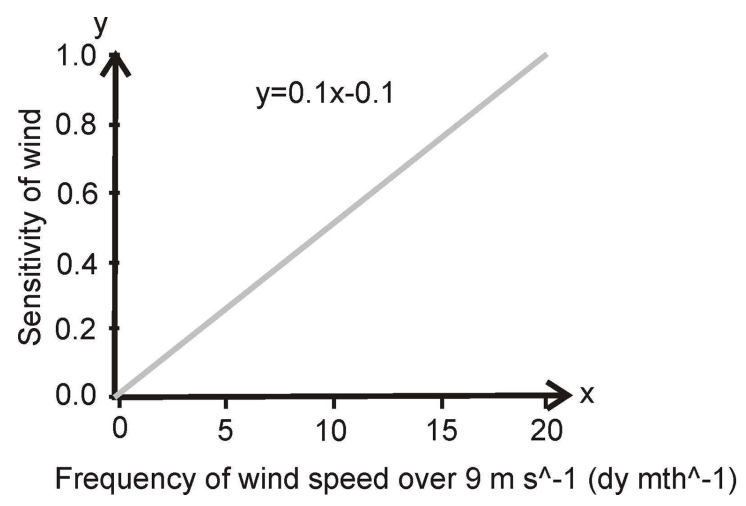

Figure 8. The applied linear fuzzy membership function of the relation between the frequency of erosive winds and the sensitivity to wind erosion. To define the frequency of erosive winds, days with a maximum wind speed above $9 \mathrm{~m} \mathrm{~s}^{-1}$ were used.

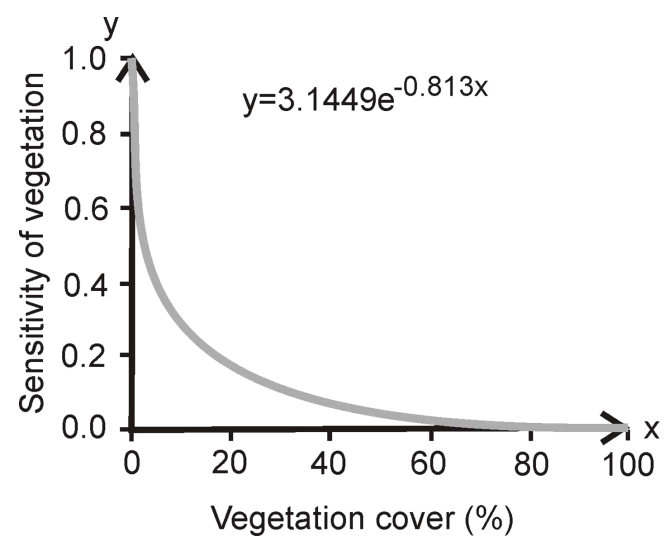

Figure 9. Relation between the vegetation cover and the sensitivity to wind erosion (NAM, 2002). The vegetation cover was calculated on the basis of a well-established direct relationship exists between the vegetation intensity and the NDVI (Huete et al., 2002).

wind parameter, the fuzzy membership function is "linear" and monotonously increasing (Fig. 8).

c. The relation between the vegetation cover and the rate of wind erosion, however, is reciprocal $(1 / \mathrm{x})$, where the increasing vegetation density causing reduction of the sensitivity of wind erosion. The rate of wind erosion is strongly reduced if the vegetation cover is higher than 20-35\% (Armbrust and Bilbro, 1997; Munson et al., 2011; NAM, 2002). If the vegetation cover exceeds $60 \%$, the sensitivity is 0 . Thus, the greater the percent vegetation cover, the smaller the sensitivity to wind erosion. The fuzzy membership function is "J-shaped" and monotonically decreasing (Fig. 9).

Integration of the sensitivity layers using fuzzy analysis: The overall fuzzy analysis for the soil, climate and vegetation factors was carried out by IDRISI Taiga software (Clark 


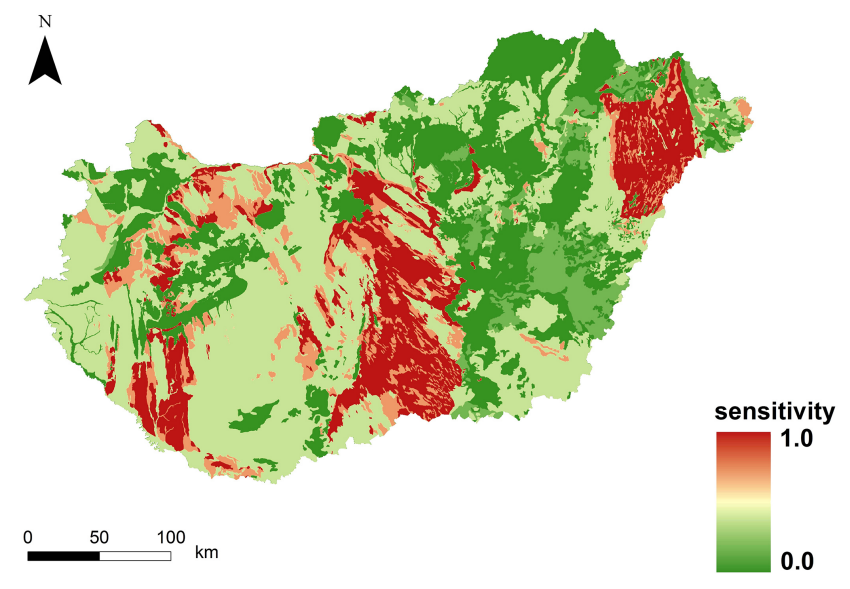

Figure 10. Sensitivity of soil texture to wind erosion based on soil erodibility index.

Labs, Worcester, MA). A sensitivity map of wind erosion was created separately for each factor, and a summary map was produced by averaging the effects of all of the factors. Thus, in the final sensitivity assessment, each factor was given equal weight.

\section{Results and discussion}

By using the above-described relations between the rate of wind erosion and the contributing factors, sensitivity maps were produced first for each factor. These maps show the spatial distribution of the sensitivity of the single factors contributing to wind erosion. Simply averaging the factors was practical for a regional-scale analysis because the relations between the factors are not documented with physical or field measurements in this scale. Moreover, the aim in this study was to avoid the usage of empirical methods based on the weighting of factors.

\subsection{Sensitivity of soil to wind erosion}

The sensitivity map of soil to wind erosion clearly shows the distribution of the soil texture classes. High-sensitivity areas are located in the blown sand areas of the country: in the north-eastern region, on the Danube-Tisza interfluve and in a smaller area in the south-western region. The lowest sensitivity values occur on the former floodplain of the Tisza River and its tributaries and in some areas in the mountains (Fig. 10).

\subsection{Regional distribution of erosive winds}

The highest frequency of the erosive winds, and thus the highest sensitivity, occurs in the north-western part of the country. High sensitivity can also be observed in southeast direction, in accordance with the dominant wind direction of the region. The lower frequency of the erosive winds occurs

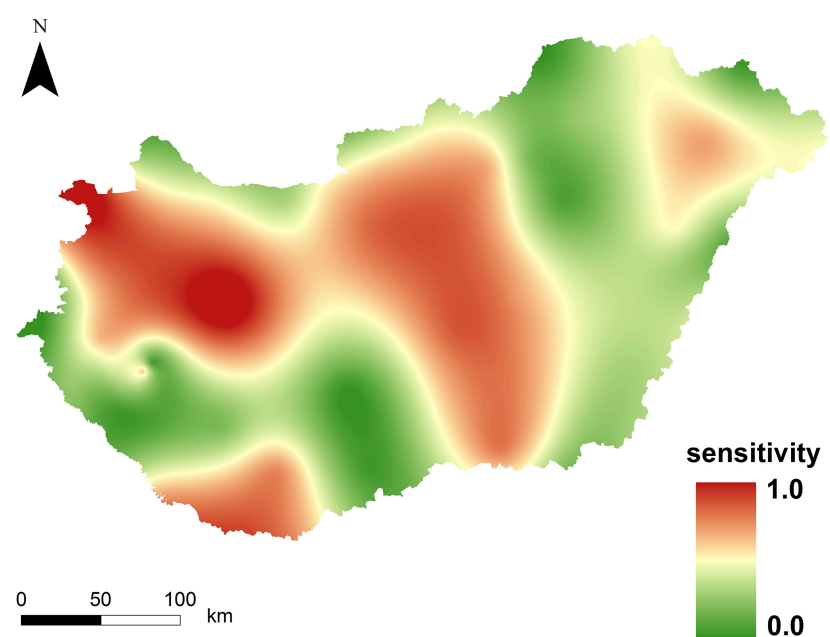

Figure 11. Sensitivity of the areas in response to the occurrence of erosive winds.

on the north-eastern region, and spatially varying frequency occurs in the south-western part of the country due to its diverse topography (Fig. 11).

\subsection{Density of the vegetation cover and sensitivity to wind erosion}

The vegetation cover-based sensitivity map indicates the highest sensitivity for the water surfaces, as these are open surfaces that have no vegetation (Fig. 12). Forests have lower sensitivity; however, during this period, the NDVI index is low for forests because the trees have yet to bud. Thus, the received sensitivity value from NDVI is not valid. To avoid the error of the final sensitivity map based on the NDVI calculation, water surfaces and forest should be excluded using the CORINE land cover map. On arable land, vegetation cover is usually not extensive but is highly variable in this period of the year.

\subsection{Early spring wind erosion sensitivity for Hungary}

The result of the calculation of sensitivity for the early spring period, when the wind erosion hazard is the highest, primarily shows the effect of soil texture and secondly the occurrence of erosive winds and the average vegetation cover in the period of 2000-2011 (Fig. 13). Accordingly, the highest sensitivity values occurred on the alluvial fans of the ancient Danube and Tisza and in the region of the Transdanubian Mountains, which are exposed to the north-western wind and covered by fluvio-aeolian loess and sand. However, the vegetation cover can significantly modify the sensitivity value at the local level.

The resulting sensitivity values were analysed on the basis of the proportion of the areas characterised by different value intervals (Table 3 ). The area was calculated in 0.1 sensitivity intervals. Areas with a sensitivity value higher than 0.4 


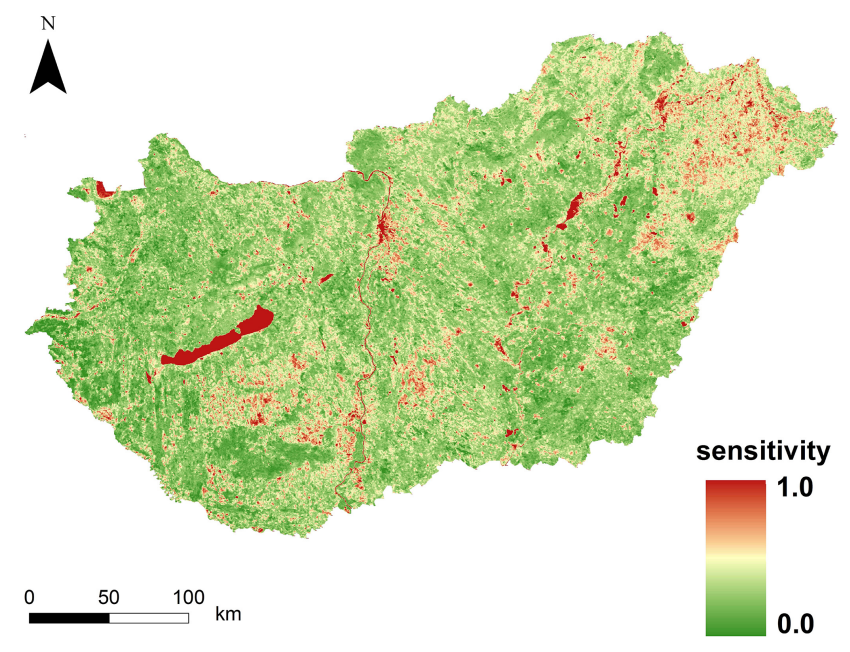

Figure 12. Sensitivity of the areas to wind erosion based on the vegetation cover.

Table 3. Spatial distribution of the sensitivity to wind erosion (calculated by soil, vegetation and wind speed data).

\begin{tabular}{lll}
\hline Fuzzy value intervals & Area $(\%)$ & Sensitivity \\
\hline $0.0-0.1$ & 10.14 & Low \\
$0.1-0.2$ & 39.93 & \\
\hline $0.2-0.3$ & 29.51 & Medium \\
$0.3-0.4$ & 6.15 & \\
\hline $0.4-0.5$ & 3.78 & \\
$0.5-0.6$ & 7.42 & \\
$0.6-0.7$ & 3.06 & High \\
$0.7-0.8$ & 0.01 & \\
$0.8-0.9$ & 0.004 & \\
\hline
\end{tabular}

are regarded hazardous. This sensitivity category covers approximately $14.27 \%$ of the country. This result agrees with the results of previous research, as Lóki (2005) and Lóczy et al. (2012) categorised $17.1 \%$ of the country as strongly prone to wind erosion hazards.

There is a practical demand for estimates of $\mathrm{tha}^{-1}$ soil loss values on the basis of the sensitivity map. However, the uncertainty in the estimates of several of the contributing factors, the applied method and their cumulative effects is hardly quantified and these factors can highly modify the actual rate of soil losses. Uncertainties can arise on the one hand from the applied data sets. These data sets are low resolution data sets (e.g. MODIS satellite images have $250 \mathrm{~m}$ resolution, wind speed data are available only on 52 stations) which are suitable for regional scale estimations, however the spatial variability of the local conditions has a much smaller scale, thus the results are not valid on a local scale. On the other hand uncertainty arises from the applied fuzzy membership functions and the integration of the sensitivity layers even if the applied fuzzy logic reduces the uncertainty com-

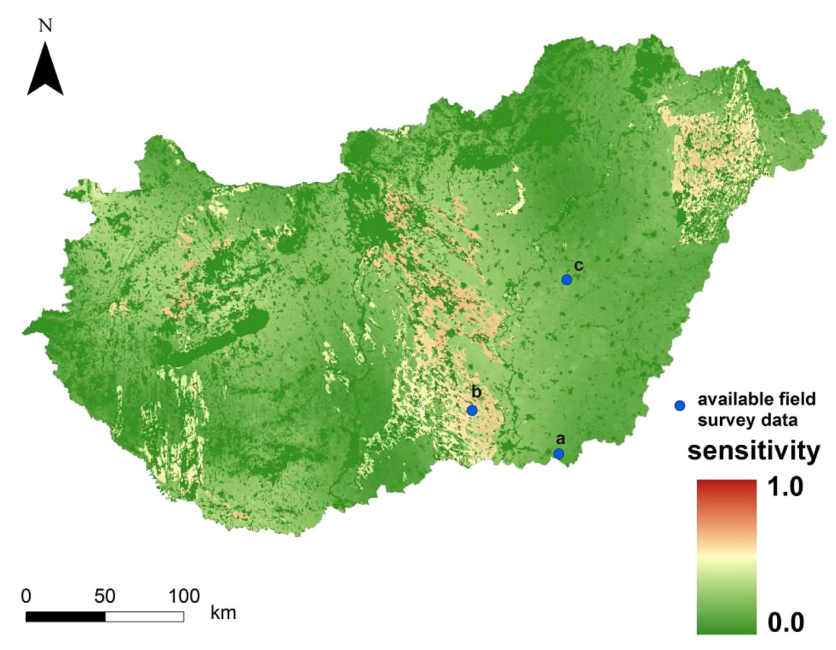

Figure 13. Wind erosion sensitivity at a regional level with a land cover mask to exclude forests and urbanised areas and the study sites for validation where field survey data are available (a Apátfalva, b Kömpöc, c Tisza plain).

pared to rough classification. Moreover the same $\mathrm{tha}^{-1}$ soil loss value can be produced by different combinations of the contributing factors.

In Hungary, only a few field survey analyses have been carried out; thus, the results of this analysis cannot adequately statistically corroborate the results of the plot-sized field survey results.

On the basis of these field measurements, the average rate of wind erosion varies between 30 and $240 \mathrm{tha}^{-1} \mathrm{yr}^{-1}$ (Borsy, 1986; Lóki, 2003; Szatmári, 2004). The occurrence of the maximum value necessitates that the vegetation cover is below $35 \%$, the wind speed exceeds $9 \mathrm{~m} \mathrm{~s}^{-1}$ and the soil texture is sand or silty sand.

Because land cover is an important modifying factor of the rate of wind erosion in our regional analysis, the CORINE land cover database was used to select the urbanised areas, other built-up areas, water surfaces and forests where wind erosion does not usually occur. The sensitivity map was overlaid with these selected areas to include only the agricultural land prone to wind erosion (Fig. 13).

\subsection{Testing and verifying the results in Hungary}

Verifying the regional results is difficult because only a few documented field surveys are available that measure wind erosion activity and its dynamics in Hungary. These measurement examples were carried out using different measurement techniques. Because of the lack of field data and the diversity of measurement techniques applied, a statistical verification or validation of the field survey data and our new sensitivity map is not possible. The results in Fig. 13 can only be compared locally to documented plot data. To test the model results, three study sites were selected (Fig. 13). 
These study sites were arable lands with poor sandy soils, solonetz meadow soils and chernozems.

a. At the first site, at Apátfalva (located near the Hungarian-Romanian border), field measurements were made on open, non-vegetated chernozem soil plots (Fig. 13a). The sensitivity values for this area varied between 0.19 and 0.27 . Field measurements of sediment transport were conducted using a high-efficiency outdoor wind tunnel. The estimated average soil loss varied between 25 and $175 \mathrm{tha}^{-1}$, but these high values occurred at very high $14-15 \mathrm{~m} \mathrm{~s}^{-1}$ wind speeds. The results underscore the previous results suggesting that the volume of transported soil increases exponentially with increasing wind speed (Farsang et al., 2011).

b. The second study site is located near Kömpöc (DanubeTisza Interfluve), where plot-sized measurements have been applied using saltiphone and erosion pegs since 1997 (Fig. 13b). On the unconsolidated sandy soil, 40$150 \mathrm{tha}^{-1}$ soil was eroded by $5-6 \mathrm{~m} \mathrm{~s}^{-1}$ winds. The maximum value was $230 \mathrm{tha}^{-1}$ which was measured at a much higher wind speed. Measurement was not continuous; only the effects of 3-5 wind erosion events were measured (Mezősi and Szatmári, 1998; Szatmári, 2004). The sensitivity value in this area is 0.57 on the new map (Fig. 13).

c. The third site represents compacted soil with high clay content and is located on the Tisza Plain (Fig. 13c). The relationship between the material eroded by various wind speeds and the grain-size distribution of the soil was measured with a sand-collector in field conditions and in a wind tunnel (Blaskó et al., 1995). Most of the material transported by the $7.4 \mathrm{~m} \mathrm{~s}^{-1}$ wind speed was fine sand $(0.1 \mathrm{~mm}$ grain-size $)$, whereas $10-40 \mathrm{tha}^{-1}$ of sediment was transported by extreme wind speeds. The sensitivity value in this area was 0.21 on the newly created map. Thus, the highest measured soil loss in the field occurred where the sensitivity map also indicated a high sensitivity to wind erosion. Therefore, the results of our research are in accordance with data from the field.

A second method for validation of the results uses data on the economic losses caused by wind erosion. A map of the locations and rates of economic loss between 1977 and 1988 , based on data from the state insurance company, was published by Szabó et al. (1994). We overlaid our sensitivity map with the map of losses to compare the results (Fig. 14). The areas with great economic losses and the areas with high or moderate sensitivity to wind erosion were compared. The two maps corresponded closely, and the economic losses were mainly recorded in areas defined as highly or moderately sensitive. Thus, the results of this research are in agreement with the record of damage from wind erosion. Accord-

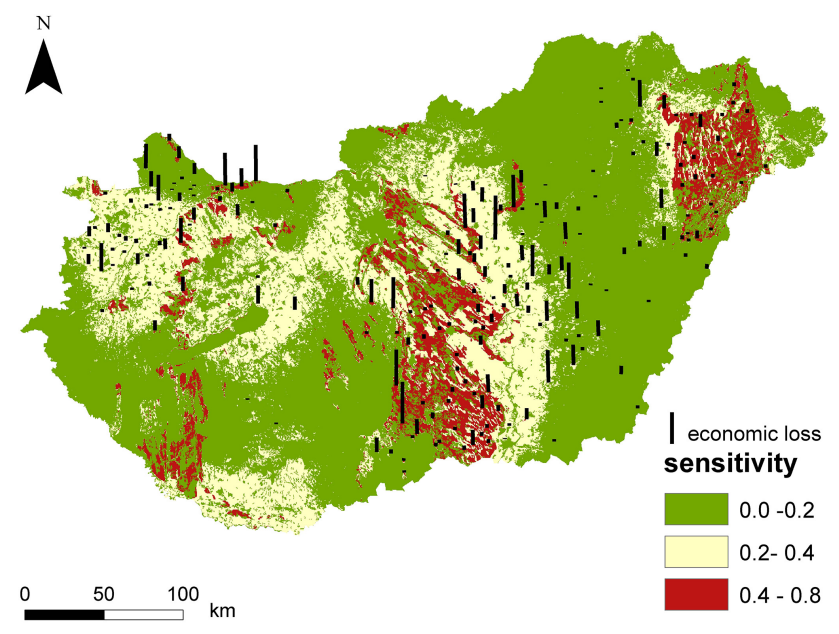

Figure 14. Economic losses based on the data from the state insurance company from the period 1977-1986 (source: Szabó et al., 1994) overlaid with the three regional sensitivity classes.

ingly, both of the validation methods support the results of the sensitivity map presented here.

\section{Conclusions}

The existing methods for estimating the rate of wind erosion on a regional level are mostly based on the geoinformatical or statistical extension of plot-based investigations. As these data are not always appropriate for scaling up, researchers have called for new parameters or new relationships for the development of regional models (Zobeck et al., 2000). In the present study, the sensitivity to wind erosion at a regional level was estimated using a newly developed method.

The risk of wind erosion was assessed using soil sensitivity, vegetation cover and wind erodibility. A MODIS data series with $250 \mathrm{~m}$ spatial resolution, a soil map at 1:25000 and wind speed data from 52 meteorological stations were used in the evaluation. Soil moisture was indirectly incorporated via vegetation density and soil data from the plot-scale erodibility factor.

The novelty in the assessment of wind erosion susceptibility presented here is found primarily in the integration of the contributing factors. Climate, vegetation and soil erodibility factors were integrated by fuzzy logic to avoid the problem of weighting. Based on field investigations, the function-based relationships between soil erodibility and the given parameters were verified. As demonstrated here in the analysis of soil erosion sensitivity, these factors are relevant at a regional scale; thus, other parameters of plot-scale investigations (e.g. surface roughness, wind barriers and wind path length) were not taken into consideration.

The areas prone to or affected by wind erosion were identified, but we could not make a quantitative estimate of the potential erosion because of the cumulative uncertainties of 
the parameters. However, wind erosion risk could be defined even at the plot scale. The highest wind erosion risk was identified in the Danube-Tisza Interfluve and in Nyírség due to the sandy soils in these areas. Similarly, a high sensitivity was detected in western Hungary, where the soil is mainly loess and loam and where more frequent and stronger winds contribute to the high sensitivity. Two critical factors affecting soil erosion include the intensive agriculture in western Hungary (mainly with wheat and maize production) and the non-vegetated soils during the spring months, when the wind erosion risk is highest.

Projections of future climate suggest that soil moisture will decrease in response to increased drought in the medium term, which will also influence areas with high wind erosion (Blanka et al., 2013; Mezôsi et al., 2013). In the future, this method should be verified with further field measurements on the plot level and by quantitatively incorporating additional data.

The resolution of the sensitivity map presented here is suitable for regional management recommendations and developing programmes to reduce wind erosion and supplements the detailed quantitative risk mapping at the plot scale. The combination of these approaches can contribute to improved land management practices.

Acknowledgements. The publication was supported by the European Union and co-funded by the European Social Fund. Project title: "Broadening the knowledge base and supporting the long-term professional sustainability of the Research University Centre of Excellence at the University of Szeged by ensuring the rising generation of excellent scientists". Project no. TÁMOP-4.2.2/B10/1-2010-0012.

Edited by: B. D. Malamud

Reviewed by: two anonymous referees

\section{References}

Agrotopographical Database, available at: http://maps.rissac.hu/ agrotopo_en/ (last access: 28 February 2013), 1991.

Armbrust, D. V. and Bilbro, J. D.: Relating plant canopy characteristics to soil transport capacity by wind, Agron. J., 89, 157-162, 1997.

Bagnold, R. A.: The Physics of Blown Sand and Desert Dunes, Methuen, London, 1-109, 1941.

Blanka, V., Mezõsi, G., and Meyer, B.: Projected changes in the drought hazard in Hungary due to climate change, Idõjárás: Q. J. Hungarian Meteorol. Serv., 117, 219-237, 2013.

Blaskó, L., Karuczka, A. Nyiri, L., and Zsembeli, J.: Kötött talajok széleróziós érzékenységének vizsgálata, Agrokémia és talajtan, 44, 497-503, 1995.

Böhner, J., Schäfer, W., Conrad, O., Gross, J., and Ringeler, A.: The WEELS model: methods, results and limitations, Catena, 52, 289-308, 2003.
Borrelli, P., Panagos, P., Ballabio, C., Lugato, E., Weynants, M. and Montanarella, L.: Towards a pan-European assessment of land susceptibility to wind erosion, Land. Degrad. Dev., doi:10.1002/ldr.2318, online first, 2014.

Borsy, Z.: Research in areas of blown sand, in: Physical Geography and Geomorphology in Hungary, edited by: Pécsi, M. and Lóczy, D., Geographical Research Institute of the Hungarian Academy of Sciences, Budapest, 77-82, 1986.

Buschiazzo, D. E., Zobeck, T. M., and Aimar, S. B.: Wind erosion in loess soils of the semiarid Argentinian pampas, Soil Sci., 164, 133-138, 1999.

Eastman, J. R.: IDRISI Andes tutorial, Worcester, MA, Clark University, 2006.

European Environment Agency: CORINE Land Cover Technical Guide: Addendum, EEA, Copenhagen, 2006.

Farsang, A., Szatmári, J., Négyesi, G., Bartus, M., and Barta, K.: Csernozjom talajok szélerózió okozta tápanyagáthalmozódásának becslése szélcsatorna-kísérletekkel, Agrokémia és talajtan, 60, 87-102, 2011.

Fryrear, D. W.: Mechanics, measurement and modeling of wind erosion, Adv. Geoecol., 31, 291-300, 1998.

Fryrear, D. W., Saleh, A., Bilbro, J. D., Schomberg, H. M., Stout, J. E., and Zobeck, T. M.: Revised Wind Erosion Equation (RWEQ), Wind Erosion and Water Conservation Research Unit, Technical Bulletin 1. Southern Plains Area Cropping Systems Research Laboratory, USDA-AR S., available at: http://www.csrl.ars.usda. gov/wewc/rweq/app.pdf (last access: 3 September 2013), 1998.

Funk, R., Skidmore, E. L., and Hagen, L. J.: Comparison of wind erosion measurements in Germany with simulated soil losses by WEP S, Environ. Modell. Softw., 19, 177-183, 2004.

Gomes, L., Arrue, J. L., Lopez, M. V., Sterk, G., Richard, D., Gracia, R., Sabre, M., Gaudichet, A., and Frangi, J. P.: Wind erosion in a semiarid agricultural area of Spain: the WEL- SONS project, Catena, 52, 235-256, 2003.

Hagen, L. J.: Evaluation of the wind erosion prediction system (WEPS) erosion submodel on cropland fields, Environ. Modell. Softw., 19, 171-176, 2004.

Huete, A., Didan, K., Miura, T., Rodriguez, E. P., Gao, X., and Ferreira, L. G.: Overview of the radiometric and biophysical performance of the MODIS vegetation indices, Remote Sens. Environ., 83, 195-213, 2002.

Jaedicke, C., Solheim, A., Blikra, L. H., Stalsberg, K., Sorteberg, A., Aaheim, A., Kronholm, K., Vikhamar-Schuler, D., Isaksen, K., Sletten, K., Kristensen, K., Barstad, I., Melchiorre, C., Høydal, Ø. A., and Mestl, H.: Spatial and temporal variations of Norwegian geohazards in a changing climate, the GeoExtreme Project, Nat. Hazards Earth Syst. Sci., 8, 893-904, doi:10.5194/nhess-8-893-2008, 2008.

Kirkby, M. J., Imeson, A. C., Bergkamp, G., and Cammeraat, L. H.: Scaling up processes and models from the field plot to the watershed and regional areas, J. Soil Water Conser., 51, 391-396, 1996.

Klik, A.: Wind erosion assessment in Austria using wind erosion equation and GIS, in: Agricul- tural Impacts on Soil Erosion and Soil Biodiversity: Developing Indicators for Policy Analysis, edited by: Francaviglia, R., Proceedings from an OECD Expert Meeting, Rome, 145-154, 2004.

Klir, G. J. and Yuan, B.: Fuzzy sets and fuzzy logic, Prentice Hall, New Jersey, 1995. 
Lakatos, M., Szépszó, G., Bihari, Z., Krüzselyi, I., Szabó, P., Bartholy, J., Pongrácz, R., Pieczka, I., and Torma, C. S.: Éghajlati szélsõségek változása Magyarországon: közelmúlt és jövõ. A magyarországi eredmények összefoglalása az IPCC szélsõséges éghajlati es- emények kockázatáról és kezelésérõl szóló Tematikus Jelentéséhez kapcsolódóan, OMSZ, Budapest, available at: http://www.met.hu/doc/IPCC_jelentes/HREX_jelentes-2012. pdf (last access: 28 August 2013), 2012.

Leenders, J. K., van Boxel, J. H., and Sterk, G.: Wind forces and related saltation transport, Geomorphology, 71, 357-372, 2005.

Li, F. R., Kang, L. F., Zhang, H., Zhao, L. Y., Shirato, Y., and Taniyama, I.: Changes in intensity of wind erosion at different stages of degradation development in grasslands of Inner Mongolia, China. J. Arid Environ., 62, 567-585, 2005.

Lóczy, D., Kertész, Á., Lóki, J., Kiss, T., Rózsa, P., Sipos, G., Sütõ, L., Szabó, J., and Veress, M.: Recent landform evolution in Hungary, in: Recent Landform Evolution, edited by: Lóczy, D., Stankoviansky, M., Kotarba, A., Springer, New York, 205-247, 2012.

Lóki, J.: Research of the land forming activity of wind and protection against wind erosion in Hungary, Riscursi şi Catastrofe, 9, 83-95, 2001.

Lóki J.: A növényzet szélerózió elleni védõhatásának vizsgálata szélcsatornában, in: Környezetvédelmi Mozaikok, edited by: Csorba, P., University of Debrecen, Debrecen, 291-306, 2003.

Lóki J.: Peculiarities and possible changes of wind erosion in Hungary as a consequence of the climate change, in: Landscapers Nature and Man, University of Debrecen, Debrecen, 101-110, 2005.

Lóki, J. and Négyesi, G.: A széleróziós információs rendszer alapjai, in: Geoinformatika és domborzatmodellezés, A HunDEM 2009 és a GeoInfo 2009 konferencia és kerekasztal válogatott tanulmányai, available at: http://www.uni-miskolc.hu/ fkt/ Hundem_es_Geoinfo_2009/Cikkek/LokiJ_NegyesiG.pdf (last access: 28 August 2013), 2009.

Lyles, L. and Krauss, R. K.: Threshold velocities and initial particle motion as influenced by air turbulence, Trans. ASA E, 14, 563566, 1971.

McBratney, A. B. and Odeh I. O. A.: Application of fuzzy sets in soil sciences: fuzzy logic, measurements and fuzzy classifications, Geoderma 77, 85-113, 1997.

MET: available at: http://www.met.hu/eghajlat/magyarorszag eghajlata/eghajlati_visszatekinto/elmult_evek_idojarasa (last access: 30 March 2013), 2012a.

MET: available at: http://www.met.hu/eghajlat/magyarorszag eghajlata/altalanos_eghajlati_jellemzes/szel/ (last access: 30 March 2013), 2012b.

MET: available at: http://www.met.hu/eghajlat/magyarorszag eghajlata/eghajlati_visszatekinto/elmult_evek_idojarasa/ (last access: 30 March 2013), 2012c.

Mezősi, G.: Environmental capabilities, hazards and conflicts in Hungary, UNIV Kiadó, Szeged, 7-103, 2011.

Mezõsi, G. and Szatmári, J.: Assessment of wind erosion risk on the agricultural area of the southern part of Hungary, J. Hazard. Mater., 61, 139-153, 1998.
Mezõsi, G., Meyer, B. C., Loibl, W., Aubrecht, C., Csorba P., and Bata, T.: Assessment of regional climate change impacts on Hungarian landscapes, Reg. Environ. Change, 13, 797-811, doi:10.1007/s10113-012-0326-1, 2013.

Munson, S. M., Belnap, J., and Okin, G. S.: Responses of wind erosion to climate-induced vegetation changes on the Colorado Plateau, PNA S, 108, 3854-3859, 2011.

NAM: National Agronomy Manual, available at: http: //directives.sc.egov.usda.gov/OpenNonWebContent.aspx? content=17894.wba (last access: 3 December 2012), 2002.

NOAA: http://gis.ncdc.noaa.gov/map/viewer, last access: 3 December 2012 .

Pásztor, L., Szabó, J., Bakacsi, Z.: Application of the digital Kreybig Soil Information System for the delineation of naturally handicapped areas in Hungary, Agrokémia és Talajtan, 59, 4756, 2010 .

Péczely, Gy.: Éghajlattan, Nemzeti Tankönykiadó, 258-285, 1998.

Shao, Y. and Leslie, L. M.: Wind erosion prediction over the Australian continent, J. Geophys. Res.-Atmos., 102, 30091-30105, 1997.

Shi, H., Gao, Q., Qi, Y., Liu, J. and Hu, Y.:Wind erosion hazard assessment of the Mongolian Plateau using FCM and GIS techniques, Environ. Earth Sci., 61, 689-697, 2010.

Skidmore, E. L.: Wind erosion, in: Soil Erosion Research Methods, edited by: Lal, R., Soil and Water Conserv. Soc., Ankeny, IA, 2nd Edn., 265-293, 1994.

Szabó, L., Karácsony, J., and Székely, Z. S.: Wind erosion problems in Hungary, Agrokémia és talajtan, 43, 109-112, 1994.

Szatmári, J.: The evaluation of wind erosion hazard for the area of the Danube-Tisza interfluve using the RWE, Q. Acta Geogr., 28, 84-95, 2004.

Tibke, G.: Basic principles of wind erosion control, Agr. Ecosyst. Environ., 22-23, 103-122, 1988.

Webb, N. P., McGowan, H. A., Phinn, S. R., and McTainsh, G. H.: AUSLEM (AUStralian Land Erodibility Model): a tool for identifying wind erosion hazard in Australia, Geomorphology, 78, 179-200, 2006.

Woodruff, N. P. and Siddoway, F. H.: A wind erosion equation, Soil Sci. Soc. Am. J., 29, 602-608, 1965.

USGSLPDAAC Data Pool Database: http://e4eil01.cr.usgs.gov: 22000/WebAccess/drill?attrib=esdt\&esdt=MOD13Q1.

5\&group=MOLT (last access: 16 January 2013), 2012.

Youssef, F., Visser, S., Karssenberg, D. J., Bruggeman, A., and Erpul, G.: Calibration of RWEQ inapatchy landscape: a first step towards a regional scale wind erosion model, Aeolian Res., 3, 467-476, 2012.

Zadeh, L. A.: Fuzzy sets, Inf. Control, 8, 338-353, 1965.

Zobeck, T. M., Parker, N. C., Haskell, S., and Guoding, K.: Scaling up from field to region for wind erosion prediction using a fieldscale wind erosion model and GIS, Agr. Ecosyst. Environ., 82, 247-259, 2000. 